\title{
Who are the Métis? The Role of Free, Prior and Informed Consent in Identifying a Métis Rights-Holder
}

Karen Drake

Osgoode Hall Law School of York University, kdrake@osgoode.yorku.ca

\section{Source Publication:}

Ibironke T Odumosu-Ayanu \& Dwight Newman, eds, Indigenous-Industry Agreements, Natural Resources and the Law (Routledge, 2021)

Follow this and additional works at: https://digitalcommons.osgoode.yorku.ca/scholarly_works

Part of the Indigenous, Indian, and Aboriginal Law Commons

\section{Repository Citation}

Drake, Karen, "Who are the Métis? The Role of Free, Prior and Informed Consent in Identifying a Métis Rights-Holder" (2021). Articles \& Book Chapters. 2843.

https://digitalcommons.osgoode.yorku.ca/scholarly_works/2843

This Book Chapter is brought to you for free and open access by the Faculty Scholarship at Osgoode Digital Commons. It has been accepted for inclusion in Articles \& Book Chapters by an authorized administrator of Osgoode Digital Commons. 
This is a post-print version of the following publication: Karen Drake, "Who are the Métis?

The Role of Free, Prior and Informed Consent in Identifying a Métis Rights-Holder" in Ibironke T Odumosu-Ayanu \& Dwight Newman, eds, Indigenous-Industry Agreements, Natural Resources and the Law (Routledge, 2021). Please cite to the published version.

\title{
WHO ARE THE MÉTIS? \\ The Role OF FrEe, PRIOR AND INFORMED CONSENT IN IDENTIFYING A MÉTIS RIGHTS-HOLDER
}

\author{
Karen Drake ${ }^{1}$
}

\section{Introduction}

The rise of the duty to consult and accommodate has generated an increase in Indigenousindustry agreements. ${ }^{2}$ For proponents tasked with carrying out the procedural aspects of the duty, Indigenous-industry agreements offer relative certainty compared to the ambiguity involved in determining whether the duty has been legally satisfied. ${ }^{3}$ For Indigenous peoples, although the drawbacks of Indigenous-industry agreements are well documented, ${ }^{4}$ these agreements can potentially instantiate the principle of free, prior and informed consent. Compared to First Nation and Inuit peoples, though, Métis rights-holders are entering into comparatively fewer Indigenous-industry agreements. ${ }^{5}$ One cause of this phenomenon is the supposed uncertainty surrounding the question of who are the Métis, which can be divided into three sub-questions: (i) Who qualifies as a Métis rights-holder to whom the duty to consult and accommodate is owed? (ii) How do we determine the geographic scope of the Métis rights-holder? (iii) Who is entitled to represent the Métis rights-holder for the purposes of engaging in consultation about the right?

\footnotetext{
${ }^{1}$ Associate professor at Osgoode Hall Law School at York University and citizen of the Métis Nation of Ontario. I wish to recognize and thank Emma Baumann and Gabrielle Pellerin for their valuable research assistance. I also wish to acknowledge and thank Jason Madden and Megan Strachan for their insights in formulating the topic of this paper. Views expressed in this paper are my own and do not necessarily reflect those of the Métis Nation of Ontario. All errors are my own.

${ }^{2}$ See Dwight Newman, "The Rule and Role of Law: The Duty to Consult, Aboriginal Communities, and the Canadian Natural Resource Sector" (May 2014) Macdonald-Laurier Institute Papers Series at 12-13 [Newman, "Role of Law"].

${ }^{3}$ See Newman, "Role of Law", ibid at 13; Dwight Newman, Natural Resource Jurisdiction in Canada (Markham, ON: Lexis Nexis Canada, 2013) at 99.

${ }^{4}$ See e.g. Emilie Cameron \& Tyler Levitan, "Impact and Benefit Agreements and the Neoliberalization of Resource Governance and Indigenous-State Relations in Northern Canada" (2014) 93 Stud Polit Econ 29; Guillaume Peterson St-Laurent \& Philippe Le Billon, "Staking Claims and Shaking Hands: Impact and Benefit Agreements as a Technology of Government in the Mining Sector" (2015) 2 Extr Ind Soc 590. ${ }^{5}$ Natural Resources Canada, Agreements Between Mining Companies and Aboriginal Communities or Governments (Ottawa: Minerals and Metals Sector, Natural Resources Canada, 2013), online: <www.nrcan.gc.ca/sites/www.nrcan.gc.ca/files/mineralsmetals/files/pdf/abor-auto/aam-eac-e2013.pdf〉.
} 
Recently, governments have sought to avoid the duty to consult and accommodate by attempting to insert these three sub-questions into the test for triggering the duty to consult and by arguing that Métis rights-holders cannot satisfactorily answer the three sub-questions. If the duty is not triggered, proponents have little or no incentive to negotiate an Indigenous-industry agreement. The lower court decisions adopting the three sub-questions should be rejected because they contradict Supreme Court of Canada jurisprudence affirming a low threshold for triggering the duty to consult. ${ }^{6}$ In the meantime, to get to the negotiation table, Métis rightsholders need a strategy for answering these three sub-questions.

In this chapter, I examine the jurisprudence on the three sub-questions with a focus on the latter two, given the exhaustive literature already devoted to the first. ${ }^{7}$ I argue that the Métis Nation of Ontario's approach to consultation — which has been lauded by independent experts 8 not only provides clear answers to the three sub-questions but also ensures consent given by the Métis Nation of Ontario to Indigenous-industry agreements is fully informed. The Métis Nation of Ontario's approach can guide other Aboriginal peoples seeking to enter into Indigenousindustry agreements.

Readers who are unfamiliar with the Métis nation may desire, at the outset, a definition of Métis people. This is precisely the issue raised by the three sub-questions discussed throughout this chapter, and especially by the first sub-question. In the context of this analysis, any pithy, introductory definition of the Métis would be unhelpful. ${ }^{9}$

\footnotetext{
${ }^{6}$ See Jason Madden, Zachary Davis \& Megan Strachan, "Recent Legal Developments on Métis Consultation in Alberta: A Case Summary of MNA Local \#125 v. Alberta" (Pape Salter Teillet LLP) at 3, 8, online: <http://albertametis.com/wp-content/uploads/2017/03/PST-LLP-Summary-MNA-125-Local-vAlberta-Feb-2017-2.pdf>. See also Mikisew Cree First Nation $v$ Canada (Minister of Canadian Heritage), 2005 SCC 69 at paras 34, 55 [Mikisew Cree]; Rio Tinto Alcan Inc v Carrier Sekani Tribal Council, [2010] 2 SCR 659 at para 40.

${ }^{7}$ See Kerry Sloan, "Always Coming Home: Metis Legal Understandings of Community and Territory" (2016) 33 Windsor YB Access to Just 125; Chris Andersen, "Métis": Race, Recognition, and the Struggle for Indigenous Peoplehood (Vancouver: UBC Press, 2014) [Andersen, "Métis"]; Sébastien Grammond \& Lynne Proulx, "Finding Metis Communities" (2012) 32:1 Canadian Journal of Native Studies 33; D'Arcy Vermette "Colonialism and the Process of Defining Aboriginal People" (2008) 31 Dalhousie LJ 21; Paul LAH Chartrand, "Defining the 'Métis' of Canada: A Principled Approach to Crown-Aboriginal Relations" in Frederica Wilson \& Melanie Mallet, eds, Métis-Crown Relations: Rights, Identity, Jurisdiction, and Governance (Toronto: Irwin Law, 2008) 27; Larry N Chartrand, "The Definition of Métis Peoples in Section 35(2) of the Constitution Act, 1982" (2004) 67 Sask L Rev 209; Catherine Bell, "Who are the Metis People in Section 35(2)?" (1991) 29 Alta L Rev 351.

${ }^{8}$ See Thomas Isaac, A Matter of National and Constitutional Import: Report of the Minister's Special Representative on Reconciliation with Métis: Section 35 Métis Rights and the Manitoba Metis Federation Decision (June 2016) at 21, online: <www.aadnc-aandc.gc.ca/eng/1467641790303/1467641835266>; Bryn Gray, Building Relationships and Advancing Reconciliation through Meaningful Consultation: Report to the Minister of Indigenous and Northern Affairs (May 30, 2016) at 21, online: <www.aadncaandc.gc.ca/eng/1498765671013/1498765827601>.

${ }^{9}$ Those who are unable to read further without some guidance about the definition of 'Métis' can read the text accompanying notes $30-34$ in section 3.1 below.
} 


\section{The Duty to Consult and Accommodate and the Principle of Free, Prior and Informed Consent}

Proponents may be reluctant to enter into Indigenous-industry agreements with the Métis for two reasons: first, proponents might assume that consent is required from the Métis nation less often than it is required from First Nation or Inuit peoples. Second, governments have argued that the duty is not triggered if the rights-bearing Métis people cannot be sufficiently identified. ${ }^{10}$ This section dispels the first concern; subsequent sections address the second concern.

The duty to consult and accommodate arises in at least three distinct situations, only two of which are discussed here: asserted rights and established rights. ${ }^{11}$ First, the duty arises when Aboriginal rights protected by section 35(1) of the Constitution Act, $1982^{12}$ are asserted but not yet proven in court or admitted by the Crown. ${ }^{13}$ In the context of asserted rights, the Crown is not required to obtain the consent of the affected Aboriginal people; that is, the Supreme Court of Canada has held that Aboriginal peoples do not have a veto prior to Crown or court recognition of their rights. ${ }^{14}$ The duty is not a duty to agree. ${ }^{15}$

Second, the duty to consult and accommodate continues to apply even after Aboriginal rights have been established in court. At this stage, though, the duty to consult and accommodate is only one of several requirements that governments must satisfy in order to justify an infringement of an Aboriginal right. ${ }^{16}$ Unlike the context of asserted rights, in some cases of established rights - such as established Aboriginal title - the Crown must obtain the full consent of the Aboriginal people before courts will allow the Crown to infringe the right. ${ }^{17}$

To summarize, consent is not required in the context of asserted rights but can be required in some cases of established rights. Given the dearth of appellate level decisions about the Aboriginal rights of the Métis compared to the Aboriginal rights of First Nations, ${ }^{18}$ proponents might assume that Métis rights are primarily asserted and not established. When consent is not required because the right is merely asserted, proponents might assume they have less incentive to negotiate an Indigenous-industry agreement.

${ }^{10}$ Fort Chipewyan Métis Nation of Alberta Local \#125 v Alberta (Minister of Aboriginal Relations), 2016 ABQB 713 at para 269 [FCMNA Local \#125].

${ }^{11}$ The third is the treaty context, which is not entirely analogous to the situation in which Aboriginal rights are asserted but not yet proven or admitted by the Crown: Mikisew Cree, supra note 6 at para 48 .

${ }_{12}$ Constitution Act, 1982, being Schedule B to the Canada Act 1982 (UK), 1982, c 11.

${ }^{13}$ Haida Nation v British Columbia (Minister of Forests), 2004 SCC 73 at paras 16, 18, 36 [Haida Nation].

${ }^{14}$ Haida Nation, ibid at para 48

${ }^{15}$ Haida Nation, ibid at para 42.

${ }^{16} R$ v Sparrow, [1990] 1 SCR 1075 at 1113-1119 [Sparrow]. Tsilhqot'in Nation v British Columbia, 2014 SCC 44 at paras 77, 80 [Tsilhqot'in Nation].

${ }^{17}$ Haida Nation, supra note 13 at paras 48, 40, citing Delgamuukw v British Columbia, [1997] 3 SCR 1010 at para 168 [Delgamuukw]; Tsilhqot'in Nation, supra note 16 at 92.

${ }^{18}$ See Karen Drake \& Adam Gaudry, “"The lands...belonged to them, once by the Indian title, twice for having defended them..., and thrice for having built and lived on them': The Law and Politics of Métis Title" (2016) 54:1 Osgoode Hall Law Journal 1 at 1. 
The legal reality, though, is more nuanced than this simple binary between asserted and established rights might suggest. Rights which are asserted either are, or should be, in the process of being established or admitted, given the Crown's obligation to negotiate a resolution of asserted Aboriginal rights, which is a legal duty on the Crown and not merely a moral or political exhortation. ${ }^{19}$ What happens if the Crown approves a project while the right is merely asserted, without obtaining the consent of the Aboriginal people, and then the right is subsequently established? The Supreme Court of Canada in Tsilhqot'in Nation explains that in this scenario, the Crown might be required to cancel the project. ${ }^{20}$ This is true even if the Crown fully satisfied the duty to consult and accommodate as it existed at the time when the right was still merely asserted. As the Court states, "the level of consultation required may change as the process goes on and new information comes to light." ${ }^{21}$ Proponents might be tempted to engage in the minimum level of consultation and accommodation required at the time of project approval. But if proponents want to avoid having their projects subsequently cancelled, obtaining the full consent of the affected Aboriginal peoples from the outset, even when the right is merely asserted, is the most prudent course of action. ${ }^{22}$ Consent is typically secured through an Indigenous-industry agreement.

One might assume that consent need not be obtained from the Métis nation because it is incapable of satisfying the test for Aboriginal title. This assumption is a mistake. As Adam Gaudry and I have argued elsewhere, the arguments in favour of Métis title are compelling. ${ }^{23}$

Proponents seeking the certainty provided by Indigenous-industry agreements would do well to ensure the consent obtained from the relevant Aboriginal people is genuine. As Dwight Newman recognizes, Indigenous-industry agreements may be subject to legal challenge when members of the Aboriginal people disagree about their governance structure and about the terms of the agreement. ${ }^{24}$ The principle of free, prior and informed consent can provide guidance to proponents who want to ensure the consent of Indigenous signatories to Indigenous-industry agreements is genuine in order to protect themselves from future legal challenges. Section 3.3 below analyzes the Métis Nation of Ontario's consultation procedures to show how these procedures ensure that consent given by the Métis Nation of Ontario to an Indigenous-industry agreement is truly informed. But first, sections 3.1 and 3.2 below discuss the first two subquestions identified in the introduction, given that the third sub-question builds on issues raised by the first two.

\footnotetext{
${ }^{19}$ Tsilhqot'in Nation, supra note 16 at para 17, citing Haida Nation, supra note 13 at para 25.

${ }^{20}$ Tsilhqot'in Nation, ibid at para 92.

${ }^{21}$ Haida Nation, supra note 13 at para 45.

${ }^{22}$ See John Borrows, "Wise Practices in Indigenous Economic Development and Environmental Protection" at 24.

${ }^{23}$ Drake \& Gaudry, supra note 18.

${ }^{24}$ Dwight Newman, "Political Rhetoric Meets Legal Reality: How to Move Forward on Free, Prior and Informed Consent in Canada" (August 2017) Macdonald-Laurier Institute Papers Series at 15 [Newman, "Legal Reality"].
} 


\section{Identifying Métis Rights-Holders to Whom the Duty to Consult and Accommodate Is Owed}

\subsection{First Sub-Question: Who Qualifies as A Métis Rights-Holder?}

A section 35 Aboriginal right is held by an Aboriginal collective. ${ }^{25}$ Although Aboriginal and treaty rights can be exercised or assigned to individuals, the rights-holder is the collective, ${ }^{26}$ in contrast to the liberal paradigm in which the rights-holder is the individual. ${ }^{27}$ Powley affirms the collective nature of Métis Aboriginal rights. ${ }^{28}$ Because the right is held by the collective, the duty to consult and accommodate is owed to the collective as opposed to being owed to individuals. ${ }^{29}$

This brings us to the first sub-question of who qualifies as a rights-bearing Métis people. The Supreme Court of Canada in Powley answered this question by quelling the Métis-as-mixed approach according to which the term "Métis" refers to a race-based category, such that the Métis are merely a collection of individuals with mixed ancestry. ${ }^{30}$ Instead, the Supreme Court in Powley adopted something closer to a nationhood approach, which holds that the term "Métis" refers "to distinctive peoples who, in addition to their mixed ancestry, developed their own customs, way of life, and recognizable group identity separate from their Indian or Inuit and European forebears. ${ }^{31}$ In other words, the offspring of the initial unions between European men and First Nations women were individuals who merely possessed mixed European and First Nations ancestry. ${ }^{32}$ But over the course of successive generations, a distinct Métis culture and collective identity emerged which was separate and distinguishable from either First Nations or European cultures. ${ }^{33}$ To be rights-bearing, according to Powley, such collectives must have emerged prior to the effective imposition of European control. ${ }^{34}$

The Métis Nation of Ontario has made substantial progress toward identifying the areas in Ontario where a distinctive Métis people emerged who developed their own customs, traditions, and collective identity prior to European control. Since 2004—shortly after the release

\footnotetext{
${ }^{25}$ Behn v Moulton Contracting Ltd, 2013 SCC 26 at paras 30, 35 [Behn].

${ }^{26}$ Behn, ibid at para 33.

${ }^{27}$ See Dale Turner, This is not a Peace Pipe: Towards a Critical Indigenous Philosophy (Toronto:

University of Toronto Press, 2006) at 13; Gordon Christie, "Law, Theory and Aboriginal Peoples" (2005)

2 Indigenous LJ 67 at 81.

${ }^{28} R$ v Powley, 2003 SCC 43 at para 24 [Powley].

${ }^{29}$ Behn, supra note 25 at para 30. See also Beckman v Little Salmon/Carmacks First Nation, 2010 SCC 53 at para 35.

${ }^{30}$ Powley, supra note 28 at para 10.

${ }^{31}$ Powley, ibid at para 10. See also $R$ v Blais, 2003 SCC 44 at para 9; FCMNA Local \#125, supra note 10 at para 191. But see Andersen, "Métis", supra note 7 at ch 4.

${ }^{32}$ See Jason Madden, "The Métis Nation's Self-Government Agenda: Issues and Options for the Future" in Frederica Wilson \& Melanie Mallet, eds, Métis-Crown Relations: Rights, Identity, Jurisdiction, and Governance (Toronto: Irwin Law Inc, 2008) 323 at 327 [Madden, "Self-Government Agenda"]. See also Report of the Royal Commission on Aboriginal Peoples: Perspectives and Realities, vol 4 (Ottawa: Canada Communication Group-Publishing, 1996) at 199-200 [RCAP, Perspectives], cited in Powley, supra note 28 at para 10.

${ }_{33}$ Powley, ibid at paras 10-11, 23; Madden, "Self-Government Agenda", ibid; RCAP, Perspectives, ibid.

${ }^{34}$ Powley, ibid at paras 10, 17, 18.
} 
of the Powley decision - the Métis Nation of Ontario and the province of Ontario have worked collaboratively to identify seven historic Métis communities in Ontario who satisfy the requirements set out in Powley and outlined above. ${ }^{35}$ The Métis Nation of Ontario cautions that the research underlying the recognition of these seven communities is not comprehensive, but rather is based on information available to date. ${ }^{36}$ As research continues, these communities may be expanded and/or additional historic Métis communities in Ontario may be identified. ${ }^{37}$

Although various additional requirements must also be met before a Court will uphold a Métis right, the Métis Nation of Ontario's research provides a useful starting point for proponents seeking to identify a Métis rights-holder in Ontario.

Outside Ontario, the only Métis rights-holder identified by Canadian courts is "the Métis Nation of the Northwest" 38 whose homeland extends into "much of the three prairie provinces, west into northern British Columbia, east into parts of Ontario, north into the Northwest Territories, and south into Montana and North Dakota" ${ }^{39}$ but does not reach east of Ontario. Although many individuals have claimed to exercise Métis rights east of Ontario, all such claims have failed; courts have never recognized a Métis rights-holder east of Ontario. ${ }^{40}$ Although the Court of Appeal of Newfoundland and Labrador affirmed that the Labrador Métis Nation was owed a duty to consult, ${ }^{41}$ the Labrador Métis Nation subsequently changed its name to Nunatukavut, reflecting that it is an Inuit, not a Métis, people. ${ }^{42}$

\subsection{Second Sub-Question: What Is the Geographic Scope of the Métis Rights-Holder?}

The second sub-question asks: what are the geographic boundaries of the collective where the right can be exercised? On the one hand, some Métis advocates assert that the Métis rightsholder is the Métis nation. ${ }^{43}$ That is, Métis people are entitled to exercise Métis rights throughout

\footnotetext{
${ }^{35}$ Métis Nation of Ontario, "Historic Métis Communities in Ontario", online: <www.metisnation.org/registry/citizenship/historic-métis-communities/> [MNO, "Historic Métis Communities"].

${ }^{36}$ MNO, "Historic Métis Communities", ibid.

${ }^{37}$ MNO, "Historic Métis Communities", ibid.

${ }^{38}$ Jean Teillet, Métis Law in Canada (Vancouver: Pape Salter Teillet LLP, 2013) (loose-leaf 2017 supplement), ch 1 at 20.

${ }^{39}$ Adam Gaudry \& Karen Drake, "The Resilience of Métis Title: Rejecting Assumptions of Extinguishment for Métis Land Rights" in Yvonne Boyer \& Larry Chartrand, eds, Métis Rising, vol 1 (Vancouver: UBC Press, forthcoming in 2020) at $\mathrm{n} 2$.

${ }^{40}$ See Darryl Leroux, Distorted Descent: White Claims to Indigenous Identity (Winnipeg: University of Manitoba Press, 2019); Adam Gaudry \& Darryl Leroux, "White Settler Revisionism and Making Metis Everywhere: The Contemporary Evocation of Metissage in Quebec and Nova Scotia" (2017) 3:1 Journal of Critical Ethnic Studies 116.

${ }^{41}$ Labrador Métis Nation v Newfoundland, 2007 NLCA 75 [Labrador Métis Nation].

${ }^{42}$ See Teillet, supra note 38 , ch 1 at 21.

${ }^{43}$ See e.g. Jean Teillet \& Carly Teillet, "Devoid of Principle: The Federal Court Determination That Section 91(24) of the Constitution Act, 1867 Is a Race-Based Provision" (2016) 13 Indigenous LJ 1 at 11. See also Larry Chartrand, "The Constitutional Determination of a Métis Rights-Bearing Community: Reorienting the Powley Test" in Karen Drake \& Brenda Gunn, Renewing Relationships: Indigenous
} 
the homeland of the Métis nation. ${ }^{44}$ On the other hand, governments have advocated for a narrow definition which limits a Métis rights-holder to "a site-specific physical settlement (village site and surrounding environs) that is local and fixed in nature" 45 or in other words, to "dots on a map around which boundary circles can be drawn (i.e., the 'hub and spoke' approach)". 46 The latter view results in limited and constricted exercises of rights. This issue is complicated by the current controversy between the Métis National Council and one of its Governing Members, the Métis Nation of Ontario, in which the Métis National Council asserts that the geographic scope of the Métis nation extends into only a portion of Ontario and does not include six of the seven historic Métis communities identified by the Métis Nation of Ontario and the province of Ontario. ${ }^{47}$ In November 2018, the Métis National Council narrowly passed a resolution putting the Métis Nation of Ontario on probation for one year and requiring it to comply with the Métis National Council's delineation of the geographic scope of the Métis homeland as a condition of lifting its probation. ${ }^{48}$

The courts have adopted a middle ground between the nationwide approach and governments' narrower hub-and-spoke approach by defining Métis rights-holders as being regional in scope. ${ }^{49}$ The regional Métis collectives identified by courts span up to $35,000-45,000$ square kilometres and encompass thousands of Métis citizens. ${ }^{50}$

The courts' regional approach to identifying the boundaries of the Métis rights-holder suffers from two flaws which I analyze in the remainder of this section: the courts' approach is inconsistent, first, with the applicable constitutional text and second, with the broader jurisprudence on this topic. Thus, as Jason Madden recognizes, the regional Métis "communities" produced by the case law are legal fictions which fail to fully reflect historical or contemporary realities. ${ }^{51}$

Peoples and Canada (Saskatoon: Native Law Centre, 2019) at 180 [Chartrand, "Métis Rights-Bearing Community"].

${ }^{44}$ For the geographical scope of the Métis nation's homeland, see text accompanying note 39.

${ }^{45}$ Chartrand, "Métis Rights-Bearing Community", supra note 43 at 175. See also Jason Madden, "Métis Consultation and Accommodation: Answering The 'Who' Question (March 2009) at n 30 [unpublished, on file with the author] [Madden, "Answering The "Who' Question"].

${ }^{46}$ Madden, "Answering The 'Who' Question", ibid at 14, 18-19.

${ }^{47}$ Clément Chartier, "Addressing the Integrity of the Historic Métis Nation Homeland: Report in

Response to the Métis Nation General Assembly December 2017 Resolution on the Métis Nation of Ontario" (November 2018) at 4, online: <http://www.metisnation.ca/wp-content/uploads/2018/11/MNONov-2018-Report-Recommendations-appendices-final.pdf>.

${ }^{48}$ Métis Nation of Ontario, "MNO responds to MNC resolutions", online:

$<$ http://www.metisnation.org/news-media/news/mno-responds-to-mnc-resolutions/>.

${ }^{49}$ See Chartrand, "Métis Rights-Bearing Community", supra note 43 at 169; Madden, "Answering The 'Who' Question", ibid at 17-18; Catherine Bell \& Paul Seaman, "A New Era for Metis Constitutional Rights: Consultation, Negotiation and Reconciliation" (2015) 38 Man LJ 29 at 64-66.

${ }^{50}$ See Madden, “Answering The 'Who' Question”, ibid at 18. See e.g. $R v$ Laviolette, 2005 SKPC 70 at paras 25-28; $R v$ Belhumeur, 2007 SKPC 114 at paras 167-68; $R v$ Goodon, 2008 MBPC 59 at para 48. The Alberta Court of Appeal in $R v$ Hirsekorn, 2013 ABCA 242, declined to address the question of the geographic scope of the Métis community, given its conclusion that no Métis community had sufficient presence in the area at issue prior to effective European control: para 8.

${ }^{51}$ Madden, “Answering The 'Who' Question”, ibid at 22. See also Teillet, supra note 38, ch 1 at 33-34. 


\subsubsection{Constitutional Text}

The applicable constitutional text is section 35 of the Constitution Act, 1982, which recognizes and affirms the existing Aboriginal rights of the Aboriginal "peoples" and includes the Métis people among Aboriginal "peoples". ${ }^{52}$ Thus, the written text stipulates that the rightsholder is a 'people'. As Larry Chartrand notes, however, the term 'people' is almost entirely missing from the courts' discussion of the issue of how to identify the Métis rights-holder. ${ }^{53}$ Instead, the term most often employed by courts when identifying the rights-holder is 'community'. ${ }^{44}$ Courts' use of the term 'community' is inexplicable, given the lack of textual foundation for it and the lack of equivalence between 'people' and 'community'. While 'people' generally connotes 'nation', Chartrand explains that 'community', from a western perspective, connotes "a static, preferably agrarian, local group as opposed to a semi-nomadic broad ranging kinship-based hunting community", the latter of which better corresponds to Métis social, legal, and political structures. ${ }^{55}$ The Court provides no explanation for substituting 'community' for 'peoples' in its analysis. ${ }^{56}$ This equivocation allows the Court to mask its departure from the textual authority that recognizes the rights-holder at the level of nationhood. ${ }^{57}$

\subsubsection{Jurisprudence}

The broader jurisprudence also supports the conclusion that the nation is the rightsholder. Powley allows for the possibility of identifying a "community" at a high level of generality: "a Métis community can be defined as a group of Métis with a distinctive collective identity, living together in the same geographic area and sharing a common way of life" as established by evidence of "shared customs, traditions, and a collective identity". ${ }^{58}$ As Chartrand explains, this definition is potentially flexible enough to support the conclusion that the rightsholder should be defined as being national in scope. ${ }^{59}$ The rights-holder is defined in terms of shared cultural markers such as customs, traditions, and a distinctive collective identity, all of which are consistent with nationhood. ${ }^{60}$

Moreover, the trial judge in Powley explicitly rejected the Crown's attempt to define the rights-holder in that case narrowly. ${ }^{61}$ Instead, the trial judge adopted the regional approach by defining the "rights-bearing Métis community" as extending, at a minimum, "hundreds of kilometres to the east, north and west of Sault Ste. Marie, spanning almost 20,000 square

\footnotetext{
${ }^{52}$ Supra note 12.

${ }^{53}$ See Chartrand, "Métis Rights-Bearing Community", supra note 43 at 171.

${ }^{54}$ Chartrand, "Métis Rights-Bearing Community", ibid at 172.

${ }^{55}$ Chartrand, "Métis Rights-Bearing Community", ibid at 171-72.

${ }^{56}$ Powley, supra note 28 at paras 11-12.

${ }^{57}$ See Chartrand, "Métis Rights-Bearing Community", supra note 43 at 171.

${ }^{58}$ Powley, supra note 28 at paras 12, 23. See also FCMNA Local \#125, supra note 10 at para 197.

${ }^{59}$ Chartrand, "Métis Rights-Bearing Community", supra note 43.

${ }^{60}$ But see Andersen, "Métis", supra note 7 at 17-20.

${ }^{61} R v$ Powley, [1999] 1 CNLR 153 (OCJ) at paras 68, 70 [Powley Trial Decision]. See also Madden,

"Answering The 'Who' Question", supra note 45 at 14-15.
} 
kilometres on the Canadian side" and reaching into northern Michigan. ${ }^{62}$ The Supreme Court of Canada upheld these findings. ${ }^{63}$ The regional approach in Powley, however, is not a precedent for rejecting the nationwide approach, given that the issue of whether the rights-holder could be defined at a nationwide level was not at issue and so was not addressed. ${ }^{64}$ Thus, as Madden concludes, it is a mistake for courts to try to replicate fictional regional Powley 'communities' if the historical evidence supports a nationwide approach. ${ }^{65}$

This issue was raised squarely in the Tsilhqot' in Nation's claim to Aboriginal title, where the trial judge applied the factors set out in Powley for identifying the rights-holder. ${ }^{66}$ The trial judge concluded that the proper rights-holder of both the claimed Aboriginal rights and title was the Tsilhqot' in people or nation - and not the individual bands or sub-entities making up the Tsilhqot'in Nation - because the shared language, customs, traditions, and historical experience required by the Powley test existed at the level of the larger nation. ${ }^{67}$ In applying these factors, the trial judge looked to the people's own traditions and customs for self-identification. ${ }^{68}$ The British Columbia Court of Appeal affirmed this approach. ${ }^{69}$ The courts identified the nation as the rights-holder, despite the absence of any overarching social or political organization or decision-making body at the national level. ${ }^{70}$ The trial judge concluded that requiring the rightsholder to have its own governance structure would be ethnocentric and would ignore Aboriginal peoples' own culture and norms. ${ }^{71}$ The Court of Appeal added that even though Tsilhqot'in governance and decision-making structures traditionally existed at the level of smaller collectives, courts must not attempt to find modern counterparts of these smaller collectives. If courts were to insist that only the smaller collective with a clear governance structure was the rights-holder, then "no one would be able to claim Aboriginal rights on behalf of the Tsilhqot'in" given the fluidity of the Tsilhqot'in political structure. ${ }^{72}$ A right without a right-holder is hollow. The province, "to its credit" — as the Supreme Court of Canada put it — did not pursue these issues at the Supreme Court of Canada. ${ }^{73}$

To summarize, the identification of a rights-holder requires cultural markers which are consistent with nationhood, but not necessarily a governance structure at the national level.

\footnotetext{
${ }^{62}$ Madden, "Self-Government Agenda", supra note 32 at 14. See also Powley Trial Decision, ibid at paras 21, 26, 28; Chartrand, "Métis Rights-Bearing Community", supra note 43 at 177.

${ }^{63}$ Powley, supra note 28 at paras 21, 26, 28.

${ }^{64}$ See Madden, "Answering The 'Who' Question", supra note 45 at 15-16; Chartrand, "Métis RightsBearing Community", supra note 43 at 187. See also Powley, ibid at para 12.

${ }_{65}^{65}$ Madden, "Answering The 'Who' Question", ibid at 16.

${ }^{66}$ Tsilhqot'in Nation v British Columbia, 2007 BCSC 1700 at paras 442, 444 [Tsilhqot'in Trial Decision].

${ }^{67}$ Tsilhqot'in Trial Decision, ibid at paras 469-70.

${ }^{68}$ Tsilhqot'in Trial Decision, ibid at paras 444, 471-72.

${ }^{69}$ Tsilhqot'in Nation v British Columbia, 2012 BCCA 285 at para 149 [Tsilhqot'in CA].

${ }^{70}$ Tsilhqot'in Trial Decision, ibid at paras 452-53.

${ }^{71}$ Tsilhqot'in Trial Decision, ibid at para 453.

${ }^{72}$ Tsilhqot'in Nation CA, supra note 69 at para 146.

${ }^{73}$ Tsilhqot'in Nation, supra note 16 at para 19. As Kent McNeil explains, the conclusion that the Tsilhqot'in Nation was the rights-holder "was implicitly affirmed by the Court's declaration of the Tsilhqot'in Nation's Aboriginal title": Kent McNeil, "Aboriginal Title and Indigenous Governance: Identifying the Holders of Rights and Authority" (2016) 12:14 Osgoode Hall Law School Legal Studies Research Paper Series at 44-45, 15-16.
} 
Villages or bands could be, but are not necessarily, rights-holders. ${ }^{74}$ The answer in any given case will depend on the rights-holder's own traditions, especially those pertaining to collective identification. ${ }^{75}$ In at least one case, the evidence indicated that each of the smaller collectives who share a common language, culture and history were the rights-holders. ${ }^{76}$ In many more cases, courts have held that the nation is the rights-holder. ${ }^{77}$

The tests applied by the courts in the Tsilhqot'in Nation case support the conclusion that the geographic scope of the Métis rights-holder can be defined at a nationhood level. Granted, the seven historic communities jointly identified by the Métis Nation of Ontario and the province of Ontario seem to be defined at a regional level, perhaps because of the limits of currently available research ${ }^{78}$ or perhaps to cohere with the current state of the jurisprudence recognizing regional Métis communities. But as mentioned above, the Métis Nation of Ontario acknowledges that eventually these communities may be expanded based on additional research. ${ }^{79}$

\subsection{Third Sub-Question: Who Is Entitled to Represent the Métis Rights-Holder for the Purpose of Consultation?}

The issue of delineating the geographic boundary of the rights-holder is distinct from the issue of determining who is entitled to represent the rights-holder for the purpose of consultation. For example, even if the rights-holder is the larger nation, a national level authority is not necessarily entitled or required to serve as the consultation representative. ${ }^{80}$ This follows from the principle discussed above that a nation who is a rights-holder need not possess a governance or decisionmaking structure at the national level. For example, the British Columbia Court of Appeal concluded that even though the Tsilhqot'in Nation was the rights-holder, a smaller entity within the nation - the Xeni Gwet'in - was the custodian of the specific area at issue and thus held responsibility for administering and protecting the rights, ${ }^{81}$ which presumably includes engaging in consultations. How, then, is the proper representative identified?

The jurisprudence on this issue is in its infancy. ${ }^{82}$ The Supreme Court of Canada's guidance is minimal and some of the pronouncements of lower courts reveal inconsistencies. In his report to the Minister of Indigenous and Northern Affairs, Bryn Gray warned: "Determining who speaks for asserted or established rights-holders is a fundamental issue and this needs to be

\footnotetext{
${ }^{74}$ Tsilhqot'in CA, supra note 69 at para 148; Kwicksutaineuk/Ah-Kwa-Mish First Nation v Canada (Attorney General), 2012 BCCA 193 at 77.

${ }^{75}$ See McNeil, supra note 73 at 45-46.

${ }^{76}$ Ahousaht Indian Band v Canada (Attorney General), 2009 BCSC 1494 at paras 287-365, rev'd in part on other grounds 2013 BCCA 300. See also McNeil, supra note 73 at 46.

${ }^{77}$ See McNeil, ibid; Tsilhqot'in Trial Decision, supra note 66 at para 445. For a list of decisions holding that the nation is the rights-holder, see $R v$ Bernard, 2017 NBCA 48 at para 51.

${ }^{78}$ See text accompanying note 36.

${ }^{79}$ MNO, "Historic Métis Communities", supra note 35.

${ }^{80}$ See John Borrows, "Wise Practices in Indigenous Economic Development and Environmental Protection" at 11.

${ }^{81}$ Tsilhqot'in CA, supra note 69 at para 154. See also McNeil, supra note 73 at 15.

${ }^{82}$ See McNeil, ibid at 42.
} 
resolved on a priority basis." ${ }^{83}$ For proponents wishing to overcome the ambiguity intrinsic to the duty to consult by entering into Indigenous-industry agreements, the certainty offered by such agreements will be a mirage if an authoritative representative of the rights-holder cannot be identified. As Newman explains, the potential obstacles to determining who speaks for a rightsholder correlate with the issue of how to obtain genuine consent. ${ }^{84}$ To ensure a rights-holder has genuinely consented to an Indigenous-industry agreement, the representative signatory to the agreement must have the proper authorization of the rights-holder. The following propositions can be deduced from the existing jurisprudence and are discussed in turn below. First, a rightsholder can authorize a representative, including a corporation, to engage in consultation and enforce the duty to consult on its behalf. Second, the authorization need not be specific and it can be demonstrated by the governing documents of either the rights-holder or the representative. In most circumstances, the citizenry of the rights-holder likely need not be coextensive with the members of the representative. Third, courts are divided on whether consultation can be owed to overlapping sub-entities of the rights-holder.

The Métis Nation of Ontario's innovative approach to consultation complies with the existing jurisprudence, and even reconciles some of the jurisprudential inconsistencies. In so doing, the Métis Nation of Ontario serves as an exemplar for ensuring consent is informed.

\subsubsection{A Rights-Holder Can Authorize a Representative to Engage in and Enforce Consultation}

A rights-holder is entitled to authorize a representative to engage in consultation and enforce the duty to consult and accommodate in court. The Supreme Court of Canada explains in Behn that "an Aboriginal group can authorize an individual or an organization to represent it for the purpose of asserting its s. 35 rights". ${ }^{85}$ The representative may take the form of a corporation. ${ }^{86}$ Older, lower court decisions which prevented corporations from litigating section 35 rights did so on the ground that the corporation - as distinct from the collective which is the rights-holder - has no direct interest in the right. ${ }^{87}$ Where corporations have been permitted to represent section 35 rights-holders, courts have relied on evidence that the rights-holder authorized the corporation to represent it. ${ }^{88}$

Allowing corporations to represent rights-holders is consistent with current practices of both First Nations and the Métis nation. With respect to First Nations, section 3.2 above showed that the legal entities created by legislation — band councils — are not necessarily rights-holders. Thus, First Nations sometimes incorporate entities to represent them at the nationhood level. ${ }^{89}$

\footnotetext{
${ }^{83}$ Gray, supra note 8 at 21.

${ }^{84}$ Newman, "Legal Reality", supra note 24 at 15.

${ }^{85}$ Behn, supra note 25 at para 30.

${ }^{86}$ Labrador Métis Nation, supra note 41 at para 46. See also FCMNA Local \#125, supra note 10 at paras 374, 389, 403.

${ }^{87}$ Campbell v British Columbia (Minister of Forests and Range), 2011 BCSC 448 at para 91, aff'd 2012 BCCA 274 [Campbell]; FCMNA Local \#125, ibid at para 371.

${ }^{88}$ See e.g. Labrador Métis Nation, supra note 41 at para 46. See also FCMNA Local \#125, ibid at para 403.

${ }^{89}$ See e.g. Red Chris Development Co v Quock, 2014 BCSC 2399 at para 2 [Red Chris].
} 
With respect to the Métis, for the most part, no analogue to the Indian Act exists. ${ }^{90}$ Thus, most Métis governance structures necessarily operate as not-for-profit corporations or societies. ${ }^{91}$

\subsubsection{Authorization Need Not Be Specific and It Can Be Demonstrated by the Governing Documents of Either the Rights-Holder or the Representative}

What do courts look for when assessing whether an entity has been authorized to represent a rights-bearer? This issue has been considered only recently by lower courts but not yet by the Supreme Court of Canada. In Behn, the Supreme Court of Canada held that without authorization from the First Nation, individual members of that First Nation could not assert a breach of the duty to consult and accommodate. ${ }^{92}$ The Court did not consider what would constitute sufficient evidence of authorization, because the appeal was from a decision on a motion to strike pleadings, and thus the Court was confined to the pleadings (which lacked an allegation of authorization). ${ }^{93}$

Authorization has been demonstrated in lower court decisions by the governing documents of either the representative or the rights-holder. Examples of the former include the preamble to an entity's memorandum and articles of association, ${ }^{94}$ a corporation's constitution, ${ }^{95}$ and a corporation's bylaws (suggested in obiter). ${ }^{96}$ An example of the latter is the resolution of a band council to be represented by an incorporated society. ${ }^{97}$

Must the authorization specify the precise project in question or proponent to be consulted? How specific must the authorization be? In cases where courts accepted the authorization, the purpose identified was not especially specific: these authorizations referred to an entitlement to consultation regarding Aboriginal rights, ${ }^{98}$ to promoting the interests and rights of the rights-holder, ${ }^{99}$ to representation with respect to consultation protocols and accommodation agreements, ${ }^{100}$ to advancing "constitutional, legal, political, social and economic rights" and to negotiating "agreements to advance and support the inherent right of selfgovernment and self-determination." "101 In Enge v Canada, the Federal Court held that the general objects set out in the registered society's constitution authorizing it to represent its members' legal rights - including the right of self-government — was sufficient to allow it to

\footnotetext{
${ }^{90}$ The exception is the Alberta Métis settlements legislation: see Chartrand, "Métis Rights-Bearing Community", supra note 43 at 173.

${ }^{91}$ Madden, "Answering The 'Who' Question", supra note 45 at 32.

${ }^{92}$ Behn, supra note 25 at para 31.

${ }^{93}$ Behn, ibid at paras 5, 31 .

${ }^{94}$ Labrador Métis Nation, supra note 41 at para 46.

${ }^{95}$ Enge v Northwest Territories (Department of Environment and Natural Resources, North Slave Region), 2013 NWTSC 33 at paras 205-206 [Enge v Northwest Territories]; Enge v Canada (Indigenous and Northern Affairs), 2017 FC 932 at paras 101-103 [Enge v Canada].

${ }^{96}$ FCMNA Local \#125, supra note 10 at para 422.

${ }^{97}$ Red Chris, supra note 89 at para 41.

${ }^{98}$ Labrador Métis Nation, supra note 41 at para 46.

${ }^{99}$ Enge v Northwest Territories, supra note 95 at para 206.

${ }^{100}$ Red Chris, supra note 89 at para 41.

${ }^{101}$ Enge v Canada, supra note 95 at para 102.
} 
commence an application alleging a breach of the duty to consult. ${ }^{102}$ It was not necessary for the registered society to also obtain a resolution or any other membership approval specifically authorizing the application. ${ }^{103}$ Thus, when the Alberta Court of Queen's Bench in Fort Chipewyan Métis Nation of Alberta Local \#125 v Alberta (Minister of Aboriginal Relations) implies in obiter that the authorization should indicate the "specific purpose" of the representation, ${ }^{104}$ it is out of step with prevailing jurisprudence.

The Métis Nation of Ontario's governance structure has been praised by Thomas Isaac, in his capacity as the Minister's Special Representative on Reconciliation with Métis, as an example of an entity with proper authorization to represent the rights-bearing people. ${ }^{105}$ The legal entity that gives effect to the Métis Nation of Ontario's governance structure is the Métis Nation of Ontario Secretariat (the Secretariat), which is a corporation. ${ }^{106}$ The Secretariat's Bylaws incorporate the Métis Nation of Ontario's Statement of Prime Purpose, which is the Métis Nation of Ontario's foundational constituting document and which provides that the Métis Nation of Ontario is the "representative body" of that portion of the Métis nation located within Ontario. ${ }^{107}$ The "aims and objectives" of the Métis Nation of Ontario include, among other things, "to ensure that Métis can exercise their Aboriginal and Treaty rights". ${ }^{108}$ The Secretariat, in turn, is the means by which the Métis Nation of Ontario's governance structure is given legal effect within the Canadian legal system: "It is the corporate and administrative arm of the Métis Nation of Ontario, which was created to represent and advocate on behalf of its registered citizens, and the Métis communities comprised of those citizens, with respect to their collective rights". ${ }^{109}$ These statements are sufficient to authorize the Secretariat to represent the Métis Nation of Ontario for the purposes of consultation and negotiating Indigenous-industry agreements.

Must the membership of the representative entity be coterminous with the citizenry of the rights-holder? For example, in Fort Chipewyan Métis Nation of Alberta Local \#125 v Alberta (Minister of Aboriginal Relations), the Alberta Court of Queen's Bench rejected the corporation's claim to represent the rights-holder because the corporation had 173 members but the population of the rights-holder was between 350 and 1000 individuals, and the corporation claimed to represent not only its own members but the entire population of the rights-holder. ${ }^{110}$ The Court held that "a corporate entity with a membership of less than one-fifth of the total population of [the rights-holder] cannot claim to be representative of the entire Aboriginal community for the purpose of asserting Aboriginal rights and seeking consultation."111

\footnotetext{
${ }^{102}$ Enge v Canada, ibid at 102, 108.

${ }^{103}$ Enge $v$ Canada, ibid at 108.

${ }^{104}$ FCMNA Local \#125, supra note 10 at para 404.

${ }^{105}$ Isaac, supra note 8 at 14.

${ }^{106}$ See Métis Nation of Ontario Secretariat Act, 2015, SO 2015, c 39 [Secretariat Act].

107 Statement of Prime Purpose, being "Appendix A" to Bylaws, supra note 116 at p 22 [Statement of Prime Purpose].

${ }^{108}$ Statement of Prime Purpose, ibid.

${ }^{109}$ Secretariat Act, supra note 106 at 1 st preambular paragraph.

${ }^{110}$ FCMNA Local \#125, supra note 10 at para 393.

${ }^{111}$ FCMNA Local \#125, ibid at para 411. See also Campbell, supra note 87 at paras 153, 160-61.
} 
The answer to this question must depend on the context. Logic dictates that the population of the rights-holder need not be coterminous with the membership of the corporation when the authorization comes from the rights-holder's own governance processes (and not from the corporation's governing documents). Otherwise, the authorization itself would be superfluous. ${ }^{112}$ Logic also dictates that the population of the rights-holder need not be coterminous with the membership of the corporation when the corporation represents only its own members. ${ }^{113}$

The coterminous population issue is not a concern for the Métis Nation of Ontario because it represents only its own members. The governance structure of the Métis Nation of Ontario's Secretariat includes 30 Community Councils which are subject to Community Charter Agreements between the Secretariat, the Métis Nation of Ontario, and the Community Council. ${ }^{114}$ The Community Charter Agreements provide that each Community Council represents only those who are citizens of the Métis Nation of Ontario. ${ }^{115}$ Pursuant to the Secretariat's Bylaws, the term "citizens" refers to the Secretariat's members. ${ }^{116}$ Similarly, the Métis Nation of Ontario Secretariat Act, 2015 affirms that the Secretariat represents "its registered citizens and the Métis communities comprised of those citizens". ${ }^{117}$ Having a coterminous population can promote informed consent. Consent is informed when the different positions held by those being represented are available for consideration. ${ }^{118}$ Entities who enter into Indigenous-industry agreements due to the duty to consult and who claim to represent nonmembers, run the risk of failing to achieve this aspect of informed consent.

One might object that if an Indigenous government such as the Métis Nation of Ontario wants to serve as the authorized representative of the rights-holder, it must represent each and every Métis individual located within a given territory. However, this objection is not persuasive because it attempts to impose a static, Eurocentric conception of a 'community' and it overlooks the doctrinal law, discussed above, which recognizes the fluidity of Indigenous governance structures. ${ }^{119}$ A requirement that the rights-holder must encompass every individual within a given geographic area would deny the autonomy of Métis people to constitute and reconstitute

\footnotetext{
112 This may explain why the court did not require coterminous populations in Red Chris, supra note 89 at para 41.

113 This may explain why the courts did not require coterminous populations in Labrador Métis Nation, supra note 41 at para 46, or in Enge v Northwest Territories, supra note 95 at paras 205-206.

${ }^{114}$ Métis Nation of Ontario Community Charter Agreement, online:

<www.metisnation.org/media/283015/kenora\%20metis\%20council\%20community\%20charter\%20march \%202011.pdf> [Community Charter Agreement].

${ }^{115}$ See e.g. Community Charter Agreement, ibid at $11^{\text {th }}$ preambular paragraph, s 3.2.

${ }^{116}$ MNO Secretariat Bylaws (AGA Approved August 28, 2016) at ss 1, 2, online:

<www.metisnation.org/media/653353/mno-bylaws-aug-29-2016-registered-aga-approved.pdf> [Bylaws].

${ }^{117}$ Secretariat Act, supra note 106 at 1st preambular paragraph.

118 Andrea Carmen, "The Right to Free, Prior, and Informed Consent: A Framework for Harmonious Relations and New Processes for Redress" in Jackie Hartley, Paul Joffe, and Jennifer Preston, eds, Realizing the UN Declaration on the Rights of Indigenous Peoples: Triumph, Hope and Action (Saskatoon: Purich Publishing Ltd, 2010) 120.

${ }^{119}$ Tsilhqot'in CA, supra note 69 at para 146, discussed above at text accompanying notes 71-72.
} 
themselves as they see fit. ${ }^{120}$ As the British Columbia Court of Appeal stated, difficulties in identifying a rights-holder cannot "be allowed to preclude recognition of Aboriginal rights that are otherwise proven." 121 Thus it cannot be that only representatives who have the authorization of every single Métis individual within a given geographic area are entitled to consultation, because if this were the law, there would be no authorized representatives of Métis rightsholders. A right without a right-holder is hollow. As the majority in $R v$ Van der Peet stated: "It would be entirely contrary to the spirit and intent of s. 35(1) to define aboriginal rights in such a fashion so as to preclude in practice any successful claim for the existence of such a right." 122 One might wonder about the logistics of two or more separate Métis rights-holders exercising Aboriginal rights within one and the same geographic area. This concern evaporates, however, when we recall that First Nations and Métis can have Aboriginal rights within one and the same territory and that doctrinal law allows for Aboriginal title to be held jointly by two or more Aboriginal peoples. ${ }^{123}$ It is not unusual for two or more Indigenous peoples to coordinate their various legal orders within a shared space. ${ }^{124}$ Canadian law refers to this unexceptional phenomenon as 'overlapping Aboriginal claims', which give rise to a duty to consult more than one rights-holder in one and the same geographic area. ${ }^{125}$

\subsubsection{Lower Courts Are Divided on Whether Consultation Can Be Owed to Overlapping Sub-Entities}

How do courts determine whether the larger nation or a smaller sub-entity is entitled to be consulted? As discussed above in section 3.3, the answer is not dictated by determining the geographic scope of the rights-holder. A rights-holder that exists at a national level is not necessarily entitled to consultation. Although the Tsilhqot'in Nation was the rights-holder, the Xeni Gwet'in, a smaller sub-entity, held responsibility for administering the rights in the area at issue. ${ }^{126}$ This conclusion was grounded in the Tsilhqot'in Nation's own laws, as evidenced by their modern political structure. ${ }^{127}$ Thus, Aboriginal people's laws - not the Crown and not proponents - determine who is entitled to be consulted. But what happens when both the larger national entity and the smaller entity claim to be owed consultation? Must the consultation engage every individual member or sub-collective of the rights-holder?

\footnotetext{
${ }^{120}$ See Chartrand, "Métis Rights-Bearing Community", supra note 43 at 184 . For a discussion of the Métis tradition of constituting and reconstituting jurisdiction-exercising collectives, see Adam Gaudry, Kaa-tipeyimishoyaahk - 'We are those who own ourselves': A Political History of Métis SelfDetermination in the North-West, 1830-1870 (PhD dissertation, University of Victoria, Department of Indigenous Governance, 2014) [unpublished] at ch 3.

${ }^{121}$ Tsilhqot'in CA, supra note 69 at para 151.

${ }^{122} R v$ Van der Peet, [1996] 2 SCR at para 62 [Van der Peet].

${ }^{123}$ Delgamuukw, supra note 17 at para 158.

${ }^{124}$ See Signa A Daum Shanks, "The History and Promise of Shared Space in a Section 35 World" in Karen Drake \& Brenda L Gunn, Renewing Relationships: Indigenous Peoples and Canada (Saskatoon: Wiyasiwewin Mikiwahp Native Law Centre, 2019).

${ }^{125}$ See John Borrows, "Wise Practices in Indigenous Economic Development and Environmental Protection" at 19; Dwight G Newman, Revisiting the Duty to Consult Aboriginal Peoples (Saskatoon: Purich Publishing Limited, 2014) at 69-70.

${ }^{126}$ Tsilhqot'in CA, supra note 69 at para 154. See also McNeil, supra note 73 at 15.

${ }^{127}$ Tsilhqot'in CA, ibid at para 152.
} 
Although the Supreme Court of Canada in Behn established that the duty to consult is not owed to individuals but rather to the collective rights-holder, the Court has not yet considered whether the duty can be owed to both sub-entities - such as bands or Métis community councils and locals - and to the larger Aboriginal nation to which the sub-entity belongs. ${ }^{128}$ Lower court decisions on this topic are inconsistent. In FCMNA Local \#125, the Alberta Court of Queen's Bench held that it would be "a waste of resources for the Alberta Crown to potentially have to consult with several separate organizations who state that they represent smaller or larger subsets of the same group in respect of the same interests and the same project." 129 In contrast, in Nla pamux Nation Tribal Council v Griffin, the British Columbia Supreme Court held that "the government must discharge its duty to consult by taking reasonable steps to ensure that all points of view within a First Nation are given appropriate consideration." 130 The position of the band most directly affected by a proposed landfill project differed from that of the entity representing the nation to which the band belonged. ${ }^{131}$ The provincial government implemented separate consultation processes with the band and with the entity representing the nation, which the Court concluded was appropriate. ${ }^{132}$

Even though the outcomes in these two decisions are inconsistent, their underlying policy values (efficiency vs. fully informed consultations) are not mutually exclusive, and have been reconciled within the Métis Nation of Ontario's consultation framework. By integrating the competing values from the divergent case law, the Métis Nation of Ontario's consultation framework ensures that their consent to any Indigenous-industry agreement resulting from the duty to consult is informed. The Métis Nation of Ontario has established a Lands, Resources and Consultations Branch (LRC Branch) which employs full-time staff who possess the scientific and technical expertise needed to support consultation. ${ }^{133}$ The LRC Branch provides governments with a "one-window" approach to consultation with the Métis Nation of Ontario. ${ }^{134}$ Governments can give notice of any proposed project or decision directly to the LRC Branch. ${ }^{135}$ The LRC Branch then identifies the relevant sub-entities within the Métis Nation of Ontario's governance structure who should be consulted, coordinates their consultation activities, and provides administrative and technical support to those sub-entities. ${ }^{136}$ The "one-window" approach means the onus is not on governments to attempt to determine which sub-entities need

\footnotetext{
${ }^{128}$ Behn, supra note 25 at para 31. See also Red Chris Development Co v Quock, 2006 BCSC 1472 at paras 15-16; Red Chris, supra note 89.

${ }^{129}$ FCMNA Local \#125, supra note 10 at para 408.

${ }^{130}$ Nlaka 'pamux Nation Tribal Council v Griffin, 2009 BCSC 1275 at para 73 [Nlaka'pamux Nation]. See also McNeil, supra note 73 at 37-38, 42.

${ }^{131}$ Nlaka'pamux Nation, ibid at paras 4, 7, 44.

${ }^{132}$ Nlaka'pamux Nation, ibid at para 75. The Court of Appeal upheld this aspect of the decision: 2011 BCCA 78 at paras 79, 81. See also McNeil, supra note 73 at n 132.

${ }^{133}$ See Métis Nation of Ontario, "Lands, Resources \& Consultation", online:

<www.metisnation.org/programs/lands-resources-consultations/>.

${ }^{134}$ I am indebted to Megan Strachan for this insight.

${ }^{135}$ Consultation Agreement between the Métis Nation of Ontario and the Government of Canada, as represented by the Minister of Indian Affairs and Northern Development (July 31, 2015) at s 5(b), online: <www.metisnation.org/media/652755/mno-canada-consultation-agreement-july-2015.pdf> [MNOCanada Consultation Agreement].

${ }^{136}$ MNO-Canada Consultation Agreement, ibid at ss 2(c), 2(e).
} 
to be consulted, which in turn avoids duplication of government resources from consulting with overlapping entities. The LRC Branch also helps to ensure consent is informed by providing the expertise needed to analyze data and documents; it thereby ensures Métis Nation of Ontario citizens understand the consequences of proposed projects and government decisions. ${ }^{137}$ Finally, a requirement of consent is that the "mechanism used to reach agreement must itself be agreed to by the Indigenous peoples concerned." 138 The LRC Branch helps to satisfy this requirement as it is a result of recommendations made by Métis Nation of Ontario citizens during province-wide consultations undertaken by the Métis Nation of Ontario in 2007-2008. ${ }^{139}$ As such, it is part of a mechanism used to reach consent which was previously agreed to by the Métis Nation of Ontario.

A potential downside of a "one-window" or centralized approach like that of the LRC Branch - if not executed well-is it could result in consultation becoming siloed as opposed to ensuring all who are affected have an opportunity to participate in decision-making, as emphasized in Nla'pamux Nation. The Métis Nation of Ontario has developed an innovative solution to this dilemma within its governance structure in the form of Regional Consultation Protocols which are agreements between the Métis Nation of Ontario and the Community Councils located within each of the Métis Nation of Ontario's nine regions. ${ }^{140}$ The Protocols establish Consultation Committees which include representatives from each of the relevant Community Councils. Consultation Committees are responsible for developing "a local and regional MNO citizen engagement plan" and for ensuring "all potentially affected MNO citizens are engaged and communicated with". ${ }^{141}$ By coordinating consultation at both the local and regional level and across multiple Community Councils, Consultation Committees save governments from having to undertake this potentially duplicative work. At the same time, Consultation Committees help to ensure that consent to any Indigenous-industry agreement is informed by providing a mechanism to allow all affected Métis Nation of Ontario citizens to engage in the decision-making process and contribute their views. ${ }^{142}$ Finally, like the LRC Branch, Consultation Committees are a result of recommendations made by Métis Nation of Ontario citizens during province-wide consultations undertaken by the Métis Nation of Ontario

\footnotetext{
${ }^{137}$ I am indebted to Megan Strachan for these insights regarding the benefits of the LRC Branch.

${ }^{138}$ Carmen, supra note 118.

${ }^{139}$ Towards a Consultation Framework for Ontario Métis - 2007/08 Community Consultations What We Heard Report (Ottawa: Métis Nation of Ontario, 2008) at 30-31, online:

<www.metisnation.org/media/51968/towards_a_metis_consultation_framework.pdf > [Consultation:

What We Heard]. I am indebted to Megan Strachan for this insight.

${ }^{140}$ See e.g. Consultation Protocol - Lakehead/Nipigon/Michipicoten Traditional Territories (26 May

2012) at s 2.8, 3.1(c), online:

<www.metisnation.org/media/507393/mno\%20consultation\%20protocol\%20-\%20lakehead-

nipigon\%20(region\%202).pdf> [Consultation Protocol].

${ }^{141}$ Consultation Protocol, ibid at 5.6(d), 6.1.

${ }^{142}$ The principle that the MNO's "consultation processes must provide all Métis citizens the opportunity to participate and be heard" is also reflected in Métis Nation of Ontario, Interim Statement of Principles on Métis Consultation and Accommodation and General Métis Framework for Consultation and Accommodation (17 November 2008) at 2, online:

<www.metisnation.org/media/51971/mno_interim_framework_metis_consultation.pdf >. I am indebted to Megan Strachan for these insights regarding the benefits of the Métis Nation of Ontario's Consultation Committees.
} 
in 2007-2008. ${ }^{143}$ As such, it functions as part of a mechanism for reaching consent which was agreed to by the Métis Nation of Ontario, and thus it serves to fulfill a requirement of consent.

\section{Conclusion}

Proponents are incentivized to enter into Indigenous-industry agreements in order to overcome the legal ambiguity surrounding the duty to consult, including the possibility that projects which are initially approved could be cancelled when the right is subsequently established if the Indigenous nation did not initially consent to the project. To achieve the certainty desired by proponents, consent to an Indigenous-industry agreement should be free, prior, and informed. The Métis Nation of Ontario's consultation procedures help to ensure that its consent is genuinely informed. The Métis Nation of Ontario Secretariat is a corporation that is sufficiently authorized to represent the Métis Nation of Ontario in consultations. The Secretariat does not claim to represent non-citizens of the Métis Nation of Ontario, which avoids the potential problem of consent being less than fully informed. The Métis Nation of Ontario's consultation framework also balances the competing values reflected in the jurisprudence, including efficiency and fully informed consent. Other Indigenous nations may find guidance from the various features of the Métis Nation of Ontario's consultation framework, such as its LRC Branch and its Consultation Committees.

${ }^{143}$ Consultation: What We Heard, supra note 139 at 22, 30. I am indebted to Megan Strachan for this insight. 